\title{
The influence of work motivation, job satisfaction and work discipline on employee performance in the regional secretariat of Maros district
}

\author{
Herman H, Didin \\ Universitas Negeri Makassar \\ E-mail: hermandody@unm.ac.id; didihalim68@gmail.com
}

\begin{abstract}
This study aims to determine and analyze the influence of motivation, job satisfaction, and work discipline on employee performance at the Regional Secretariat of Maros Regency. This type of research is quantitative descriptive, while the nature of the research is descriptive explanatory research. The research was conducted at the Regional Secretariat of Maros Regency. The research was carried out for 3 months. The population in this study amounted to 96 employees at the Regional Secretariat of Maros Regency. The sample in this study was the total population taken as a sample. Thus the number of samples is equal to the population (census or saturated samples). So that the sample is 96 employees at the Regional Secretariat of Maros Regency. The data analysis method used in this study is multiple regression analysis. The results showed that there was a positive and significant influence between work motivation, job satisfaction and work discipline on the performance of the Maros Regency Regional Secretariat employees.
\end{abstract}

Keywords: motivation; satisfaction; discipline; performance

\section{INTRODUCTION}

In the government system of the Republic of Indonesia, this policy direction for apparatus resource development has been outlined in various laws and regulations, including Government Regulations (PP) and Regional Regulations (Perda) in the context of implementing regional autonomy. Performance is the result of work that can be achieved in quality and quantity with full responsibility that has been determined and mutually agreed within an organization (Usman, 2017).

The performance of employees at the Regional Secretariat of Maros Regency has a phenomenon that can be seen from the attitude of employees who like to delay work, thus employees are considered less able to complete work on time. Employee performance will be influenced by the employee problems that have been stated above, if ignored, it will have a negative impact on the results of employee performance in achieving the goals set at the Regional Secretariat of Maros Regency for the future.

Motivation is a factor that creates enthusiasm or work motivation in employees to do something in order to get what employees need and to achieve the goals of the organization (Niswaty et al., 2017; Saggaf et al., 2017; Syam et al., 2018). Phenomena related to motivation at the Regional Secretariat of Maros Regency can be seen from the attitudes shown by employees such as: lack of freedom in expressing ideas or opinions and the incentives received are not in accordance with the existing work portion and abilities. 
Job satisfaction is the result of various attitudes for an employee, if a job is in accordance with the interests and expectations, the higher the level of satisfaction felt by the employee and vice versa (Pratiwi et al., 2019; Rengifurwarin et al., 2018). The phenomenon related to employee job satisfaction at the Regional Secretariat of Maros Regency can be seen from uneven workload, lack of cooperation among fellow employees and lack of input from the leadership on how well the work has been completed by employees.

Employee work discipline can be seen from the awareness that arises from within the employee without being compelled to follow the applicable regulations in an organization (Farida, 2017; Limpo et al., 2015; Rengifurwarin et al., 2018). The phenomenon of employee work discipline at the Regional Secretariat of Maros Regency can be seen from employees who are less enthusiastic in working so that the results are not as expected, a sense of low employee concern so that some office equipment is not properly maintained and employees are less disciplined in carrying out work, such as: employees are still like not coming to work and like being late to attend the electric machine above 09.00 WIB. This shows that employees do not comply with the rules set by the organization.

\section{METHOD}

This type of research is descriptive quantitative, while the nature of the research is descriptive explanatory research. The research was conducted at the Regional Secretariat of Maros Regency. The research was carried out for 3 months, from October to December 2019. The population in this study was 96 employees at the Regional Secretariat of Maros Regency. The sample in this study is the entire population taken as the sample. Thus the number of samples is equal to the population (census or saturated samples). So that the sample is 96 employees at the Regional Secretariat of Maros Regency. The data analysis method used in this research is multiple regression analysis (Creswell \& Creswell, 2017).

\section{RESULT AND DISCUSSION}

\section{Result}

To test the currently developing hypothesis, in this study the authors used several tests, namely $\mathrm{t}$ test (partial testing) and $\mathrm{F}$ test (simultaneous testing). With the help of using a data processing analysis program, which can be described and explained as follows:

\section{Partial Testing (t-test)}

To test the variable partially or individually the independent variable $(\mathrm{X})$ on the dependent variable $(\mathrm{Y})$ can be used $\mathrm{t}$ test. This can be seen in the results of the data processing analysis set out in Table 1. 
Table 1

T test results

\begin{tabular}{|l|l|l|}
\hline \multicolumn{1}{|c|}{ Model } & \multicolumn{1}{c|}{ tcount $_{\text {Cig }}$} \\
\hline Constanta & 3,012 & 0,001 \\
$\mathrm{X}_{1}$ & 2,412 & 0,000 \\
$\mathrm{X}_{2}$ & 2,105 & 0,000 \\
$\mathrm{X}_{3}$ & 3,303 & 0,000 \\
\hline
\end{tabular}

Source: Processed Data, 2019

From the description of the $t$ test using a data analysis program, it is known that the three independent / independent variables (X) significantly affect the performance of the employees of the Regional Secretariat of MAROS Regency with the following summary:

- Work motivation variable (X1) with $t_{\text {count }} 2.412>t_{\text {table }} 2.060$

- Variable job satisfaction (X2) with $t_{\text {value }} 2.105>t_{\text {table }} 2.060$

- Work discipline variable (X3) with $t_{\text {count }} 3,303>t_{\text {table }} 2,060$

\section{Simultaneous Testing (Test-F)}

The $\mathrm{F}$ test serves to test the variables of work motivation, job satisfaction and work discipline, whether the three variables studied simultaneously affect the performance of the Maros Regency Regional Secretariat employees. The analysis was carried out using data processing program tools which can be described in Table 2 .

Table 2

F Test Results

\begin{tabular}{|l|l|l|l|l|}
\hline Model & $\begin{array}{l}\text { Sum of } \\
\text { squares }\end{array}$ & Df & F & Sig \\
\hline Regression & 273.494 & 3 & 11,345 & 0,000 \\
Residual & 150,673 & 38 & & \\
Total & 426,167 & 41 & & \\
\hline
\end{tabular}

Source: Processed Data, 2019

The $\mathrm{F}_{\text {count }}$ value is 11.34 , which means the independent / independent variable $(\mathrm{X})$ which includes work motivation, job satisfaction and work discipline simultaneously affects the performance of the Maros Regency Regional Secretariat employees can be said to be significant because the test shows that the results of $F_{\text {count }}=11.34$ more the size of $F_{\text {table }}=2.70$ or it can be said that Ho is rejected and Ha is accepted.

This study also found the magnitude of the influence of the independent variables on the dependent variable which can be seen from the coefficient of determination ( $\mathrm{R}$ square) and can be seen in the following table 3 . 
Table 3

Determination Test Results

\begin{tabular}{|l|l|l|}
\hline Model & R & R Square \\
\hline 1 & 0,645 & 0,588 \\
\hline
\end{tabular}

Source: Processed Data, 2019

The coefficient of determination ( $\mathrm{R}$ square) is 0.645 which means that the independent / independent variable $(\mathrm{X})$ which includes work motivation, job satisfaction and work discipline has a contribution to the performance of the employees of the Regional Secretariat of Maros Regency by $64.5 \%$, while the remaining $35,5 \%$ is influenced by other variables not included in this study.

\section{Discussion}

\section{Effect of Motivation on Performance}

Based on the results of the research hypothesis, it is found that motivation $\left(\mathrm{X}_{1}\right)$ has a significant effect on employee performance $(\mathrm{Y})$, has a significant effect on the regression coefficient value of 0.170 because motivation is one of the parts needed to produce good performance in an employee besides it is also able to improve the performance of the Regional Secretariat of Maros Regency is in accordance with the goals desired by the leadership and the organization. If the motivation has increased by one unit, the employee's performance will increase by 0.170 with the assumption that the other independent variables have a fixed value.

According to Rozi and Sunarsi (2020), motivation is the willingness to spend a high level of effort towards organizational goals conditioned by the ability of these efforts to meet individual needs. So if someone is motivated, the employee will become strong and will lead to behavior that leads to certain goals with full commitment until the goals desired by the organization are achieved.

Motivation has a phenomenon that can be seen from the initial conditions, namely: lack of freedom in expressing ideas or opinions and the incentives received are not in accordance with the existing portion of work and abilities. So it can be said that the employees of the Regional Secretariat of Maros Regency, have poor motivation, with reference to the results of this study, employees in the organization show that with an improvement in motivation it will improve employee performance at work.

The results of this research can be proven through $t$ test analysis which shows $t_{\text {count }} 2.412>$

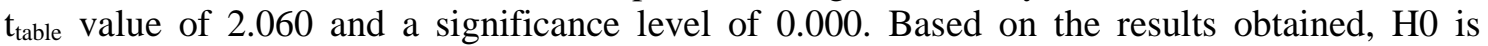
rejected and $\mathrm{H}_{1}$ is accepted for the motivation variable, so partially the motivation variable has a significant effect on employee performance.

\section{Effect of Job Satisfaction on Employee Performance}

Based on the results of the research hypothesis, it is found that the job satisfaction variable (X2) has a significant effect on employee performance (Y), has a significant effect with a regression coefficient value of 0.346 , with job satisfaction in employees means that the 
Regional Secretariat of Marost Regency has provided the most important part for employees in a pleasant atmosphere to implement the abilities they have for their work. So if job satisfaction has increased by one unit, employee performance will increase by 0.346 with the assumption that other independent variables have a fixed value.

Job satisfaction has a phenomenon that can be seen from the initial conditions, namely: from uneven workload, lack of cooperation among fellow employees and lack of input from the leadership on how well the work results have been completed by employees. So it can be said that the employees of the Regional Secretariat of Maros Regency have poor satisfaction, with reference to the results of this study, employees in the organization show that with an improvement in job satisfaction it will improve employee performance at work.

The results of the research can be proven through $t$ test analysis which shows the $t$ value of 2.105> the t table value of 2.062 and a significance level of 0.000 . Based on the results obtained, $\mathrm{H} 0$ is rejected and $\mathrm{H} 1$ is accepted for the job satisfaction variable, thus partially the job satisfaction variable has a significant effect. on employee performance.

\section{Effect of Work Discipline on Employee Performance}

Based on the results of the research hypothesis, it is found that work discipline (X3) has a significant effect on employee performance $(\mathrm{Y})$ with a regression coefficient value of 0.707 indicating that the Regional Secretariat of Maros Regency is able to direct employees to obey and obey the regulations that have become the provisions in the organization to produce better performance. good so that organizational goals can be achieved. So if the work discipline has increased by one unit, the employee's performance will increase by 0.6707 with the assumption that other independent variables have a fixed value.

Employee work discipline has a phenomenon that can be seen from the initial conditions, namely: lack of work enthusiasm so that between planning and realization does not go as expected, a low sense of employee concern so that some office equipment is not properly maintained and cared for and lacks discipline in carrying out their work such as: Employees still like not coming to work and like being late to check in on an electric machine above 09.00 WIB. So it can be said that the employees of the Regional Secretariat of Maros Regency have poor work discipline, with reference to the results of the above research, employees in the organization show that with an improvement in work discipline it will improve employee performance at work.

The results of the research can be proven through $t$ test analysis which shows the $t$ value of 3.303> the t table value of 2.062 and a significance level of 0.000 . Based on the results obtained, $\mathrm{H} 0$ is rejected and $\mathrm{H} 1$ is accepted for work discipline variables, thus partially the work discipline variable has a significant effect. and is the most dominant variable affecting employee performance. This shows that work discipline is a factor that is very supportive of all employee activities with full awareness in developing their energy and mind maximally to support organizational goals. Thus the Head of the Regional Secretariat of Maros Regency needs to improve work discipline employees so that the work atmosphere becomes more pleasant and increases enthusiasm for work, so that work activities run smoothly and get optimal results.

The results of this study support previous studies, one of which is research from (Sutrisno and Sunarsi (2019), which shows that motivation and work discipline simultaneously have a significant and positive effect on employee performance in the PT. Anugerah Agung in Jakarta. 


\section{Jurnal Administrare: Jurnal Pemikiran Ilmiah dan Pendidikan Administrasi Perkantoran}

Vol. 7, No. 1, january-June 2020, Pages 191-196. Pages 207-214

that the work discipline variable has a greater influence on employee performance. Partially each variable has a significant positive effect on employee performance.

\section{Effect of Motivation, Job Satisfaction and Work Discipline on Employee Performance}

Based on the research results that simultaneously all independent variables: motivation (X1), job satisfaction (X2) and work discipline (X3) have a significant effect on employee performance (Y). Partially, each independent variable: motivation (X1), job satisfaction (X2) and work discipline (X3) have a significant effect on employee performance (Y). Work discipline variables have a more dominant effect on employee performance, thus the Regional Secretariat of Maros Regency must pay more attention to employee work discipline variables because it plays a very important role in influencing the entire performance of the employees of the Regional Secretariat of MAROS Regency.

Based on the research hypothesis, it shows that the variables of motivation, job satisfaction and work discipline have a significant effect on the performance of the employees of the Regional Secretariat of Maros Regency. The results of the research can be proven based on the results of the research hypothesis, namely: the value of employee performance constants in the regression model is obtained at 14.057, meaning that if the value of the independent variable $(\mathrm{X})$ is 0 then the dependent variable $(\mathrm{Y})$ is 14.057 . The regression coefficient for each independent variable $(\mathrm{X})$ is positive, meaning that there is a positive effect, if each independent variable $(\mathrm{X})$ increases by one unit, the dependent variable $(\mathrm{Y})$ will increase by the value of the coefficient for each independent variable. (X).

Based on the results of the study the coefficient of determination (R2) obtained a value of $0.588(58.8 \%)$ which means that the variation of the independent variables used in the model (motivation, job satisfaction and work discipline) is able to explain $68.6 \%$ of the dependent variable (employee performance). It means that there is a strong relationship between the independent variables and the dependent variable, this can be proven by the $\mathrm{R}$ value of 0.645 $(64.5 \%)$.

According to Venclová et al. (2013), the employee performance system seeks to identify, encourage, measure, evaluate, improve, and reward employee performance. Human resources have an important role in an organization to achieve the desired goals. human resources that have better performance.

Employee performance has a phenomenon that can be seen from the initial conditions, namely: employees like to delay their work so that employees are considered unable to complete work on time. Employees are not careful in working so that in quantity they often make mistakes in completing a job. Coordination in work does not go well between superiors and subordinates so that the quality of the resulting performance is not optimal. So it can be said that the employees of the Regional Secretariat of Maros Regency have poor performance, with reference to the results of this study it is able to show that with an improvement in motivation, job satisfaction and work discipline will improve employee performance.

The results of this study support previous studies, one of which is research from Rozi and Sunarsi (2020), in his research entitled "The Influence of Motivation and Work Discipline on the Performance of PT. Anugerah Agung in Jakarta". The results showed that motivation and work discipline simultaneously had a significant and positive effect on employee performance 
in the PT. Anugerah Agung in Jakarta. Work discipline variables had a greater influence on employee performance. Partially each variable had a significant positive effect on employee performance in PT. Anugerah Agung in Jakarta.

\section{CONCLUSION}

There is a positive and significant influence of work motivation on the performance of the employees of the Regional Secretariat of Maros Regency. There is a positive and significant effect of job satisfaction on the performance of the employees of the Regional Secretariat of Maros Regency. There is a positive and significant effect of work discipline on the performance of the employees of the Regional Secretariat of Maros Regency. There is a positive and significant influence work motivation, job satisfaction and work discipline together on the performance of the employees of the Regional Secretariat of Maros Regency.

\section{REFERENCES}

Creswell, J. W., \& Creswell, J. D. (2017). Research design: Qualitative, quantitative, and mixed methods approaches. Sage publications.

Farida, U. (2017). Analysis of Empowerment Program that was Implemented in Mamuju Regency East Sulawesi Indonesia. 149(Icest), 19-21.

Limpo, H. Y., Akib, H., \& Dirawan, G. D. (2015). Policy formulation for the initiative right of people's representative councilof South Sulawesi. International Journal of Applied Business and Economic Research, 13(4).

Niswaty, R., Rusbiati, S., Jamaluddin, J., \& Salam, R. (2017). The Influence of Teacher's Reinforcement for Students Motivation. International Conference on Education, Science, Art and Technology, 148-152.

Pratiwi, N. J., Jamaluddin, J., Niswaty, R., \& Salam, R. (2019). The Influence of Work Facilities on Employee Performance at the Regional Financial Management Agency Secretariat Section of South Sulawesi Province. Jurnal Ad'ministrare, 6(1), 35-44.

Rengifurwarin, Z. A., Akib, H., Jasruddin, \& Salam, R. (2018). Snapshot of public service quality in the center for integrated business service (CIBS), cooperative micro small and medium enterprises (CMSME), Maluku province, Indonesia. Journal of Entrepreneurship Education, 21(3).

Rozi, A., \& Sunarsi, D. (2020). The Influence of Motivation and Work Experience on Employee Performance at PT. Yamaha Saka Motor in South Tangerang. Jurnal Office, 5(2), 65-74.

Saggaf, M. S., Salam, R., \& Wirawan, H. (2017). The Influence of Teacher's Pedagogic Competence on Learning Motivation of Student of Office Administration Expertise Package. 8th International Conference of Asian Association of Indigenous and Cultural Psychology (ICAAIP 2017). 
Sutrisno, S., \& Sunarsi, D. (2019). The Effect of Work Motivation and Discipline on Employee Productivity at PT. Anugerah Agung in Jakarta. Jurnal Ad'ministrare, 6(2), 187-196.

Syam, A., Hasbiah, S., Yunus, M., \& Akib, H. (2018). Determinants of entrepreneurship motivation for students at educational institution and education personnel in Indonesia. Journal of Entrepreneurship Education, 21(2).

Usman, A. (2017). Influence of Motivation on the Performance of Government Employees. 2nd International Conference on Education, Science, and Technology (ICEST 2017).

Venclová, K., Salková, A., \& Kolácková, G. (2013). Identification of employee performance appraisal methods in agricultural organizations. Journal of Competitiveness, 5(2). 